\title{
Equilibrator-based measurements of dissolved nitrous oxide in the surface ocean using an integrated cavity output laser absorption spectrometer
}

\author{
I. Grefe ${ }^{1, *}$ and J. Kaiser ${ }^{1}$ \\ ${ }^{1}$ School of Environmental Sciences, University of East Anglia, Norwich Research Park, Norwich, UK \\ *now at: Dalhousie University, Department of Oceanography, 1355 Oxford Street, Halifax NS B3H 4R2, Canada
}

Correspondence to: J. Kaiser (j.kaiser@uea.ac.uk)

Received: 28 May 2013 - Published in Ocean Sci. Discuss.: 3 July 2013

Revised: 28 April 2014 - Accepted: 1 May 2014 - Published: 19 June 2014

\begin{abstract}
Dissolved nitrous oxide $\left(\mathrm{N}_{2} \mathrm{O}\right)$ concentrations are usually determined by gas chromatography (GC). Here we present laboratory tests and initial field measurements using a novel setup comprising a commercially available laser-based analyser for $\mathrm{N}_{2} \mathrm{O}$, carbon monoxide and water vapour coupled to a glass-bed equilibrator. This approach is less labourintensive and provides higher temporal and spatial resolution than the conventional GC technique. The standard deviation of continuous equilibrator or atmospheric air measurements was $0.2 \mathrm{nmol} \mathrm{mol}^{-1}$ (averaged over $5 \mathrm{~min}$ ). The shortterm repeatability for reference gas measurements within $1 \mathrm{~h}$ of each other was $0.2 \mathrm{nmol} \mathrm{mol}^{-1}$ or better. Another indicator of the long-term stability of the analyser is the standard deviation of the calibrated $\mathrm{N}_{2} \mathrm{O}$ mole fraction in marine air, which was between 0.5 and $0.7 \mathrm{nmol} \mathrm{mol}^{-1}$. The equilibrator measurements were compared with purge-and-trap gas chromatography-mass spectrometry (GC-MS) analyses of $\mathrm{N}_{2} \mathrm{O}$ concentrations in discrete samples from the Southern Ocean and showed agreement to within the $2 \%$ measurement uncertainty of the GC-MS method. The equilibrator response time to concentration changes in water was from 142 to $203 \mathrm{~s}$, depending on the headspace flow rate. The system was tested at sea during a north-to-south transect of the Atlantic Ocean. While the subtropical gyres were slightly undersaturated, the equatorial region was a source of nitrous oxide to the atmosphere, confirming previous findings (Forster et al., 2009). The ability to measure at high temporal and spatial resolution revealed submesoscale variability in dissolved $\mathrm{N}_{2} \mathrm{O}$ concentrations. Mean sea-to-air fluxes in the tropical and subtropical Atlantic ranged between -1.6 and $0.11 \mu \mathrm{mol} \mathrm{m}{ }^{-2} \mathrm{~d}^{-1}$
\end{abstract}

and confirm that the subtropical Atlantic is not an important source region for $\mathrm{N}_{2} \mathrm{O}$ to the atmosphere, compared to global average fluxes of $0.6-2.4 \mu \mathrm{mol} \mathrm{m}{ }^{-2} \mathrm{~d}^{-1}$. The system can be easily modified for autonomous operation on voluntary observing ships (VOS). Future work should include an interlaboratory comparison exercise with other methods of dissolved $\mathrm{N}_{2} \mathrm{O}$ analyses.

\section{Introduction}

Nitrous oxide $\left(\mathrm{N}_{2} \mathrm{O}\right)$ is an important trace gas in the atmosphere, influencing Earth's climate as well as stratospheric chemistry. It is currently the third most important greenhouse gas in terms of 100 year global warming potential after $\mathrm{CO}_{2}$ and $\mathrm{CH}_{4}$ (Ravishankara et al., 2009). Furthermore, it is the main precursor of stratospheric $\mathrm{NO}_{\mathrm{x}}$, which catalytically destroys ozone (Crutzen, 1970). As chlorofluorocarbons (CFCs) are phased out under the Montreal Protocol, $\mathrm{N}_{2} \mathrm{O}$ is the most important, currently emitted substance involved in stratospheric ozone depletion (Ravishankara et al., 2009). Atmospheric concentrations are rising at a rate of $0.26 \%$ per year with the ocean contributing about $30 \%$ to total emissions (Forster et al., 2007). Bacterial nitrification and denitrification are assumed to be the main production pathways for $\mathrm{N}_{2} \mathrm{O}$ in the ocean, while denitrification can also act as a sink under suboxic conditions (Elkins et al., 1978; Cohen and Gordon, 1978; Knowles, 1982). Even though nitrification is an aerobic process, $\mathrm{N}_{2} \mathrm{O}$ production is enhanced as oxygen concentrations decrease (Goreau et al., 
1980; Yoshida et al., 1989; Yoshinari, 1976). Nitrifier denitrification is an alternative pathway for $\mathrm{N}_{2} \mathrm{O}$ production by ammonia-oxidising bacteria, which appears to be important for the near-surface $\mathrm{N}_{2} \mathrm{O}$ source (Poth and Focht, 1985; Popp et al., 2002; Sutka et al., 2006; Sutka et al., 2004). Recently, the importance of $\mathrm{N}_{2} \mathrm{O}$ production by archaeal ammonia oxidation was discovered, potentially accounting for a significant part of the oceanic $\mathrm{N}_{2} \mathrm{O}$ source (Löscher et al., 2012; Wuchter et al., 2006). The estimated source of rivers and coastal regions range currently from 0.5 to $2.7 \mathrm{Tg} \mathrm{a}^{-1}$ (in $\mathrm{N}$ equivalents) and from 1.8 to $5.8 \mathrm{Tg} \mathrm{a}^{-1}$ for the open ocean (Denman et al., 2007). In the light of the uncertainties in the marine $\mathrm{N}_{2} \mathrm{O}$ source and potential future emission increases due to ocean deoxygenation (Codispoti, 2010), accurate observations in space and time are important to give a better estimate of regional sources and global budgets.

The most common technique for $\mathrm{N}_{2} \mathrm{O}$ concentration measurements is injection of a gas sample onto a gas chromatographic column coupled to an electron-capture detector (GCECD) (Weiss, 1981; Weiss et al., 1992; Butler et al., 1989; Walter et al., 2004). Here we present an alternative method using a laser-based optical absorption analyser (Baer et al., 2002) that in combination with an equilibrator enables continuous $\mathrm{N}_{2} \mathrm{O}$ analyses at ambient levels in seawater. The system is low maintenance, can be easily calibrated and allows for higher measurement frequency than GC-ECD methods. It has the potential to facilitate observations over long time series, revealing variability and trends, as is already happening for $\mathrm{CO}_{2}$ measurement systems, e.g. on ships of opportunity. Laboratory tests and results from field deployments of the analyser in combination with an equilibrator are presented.

\section{Materials and methods}

\subsection{Laboratory tests}

The $\mathrm{N}_{2} \mathrm{O} / \mathrm{CO}$ analyser (Los Gatos Research, LGR, model $\mathrm{N}_{2} \mathrm{O} / \mathrm{CO}-23 \mathrm{~d}$ ) used in this study, measures gas-phase mole fractions of $\mathrm{N}_{2} \mathrm{O}$, carbon monoxide $(\mathrm{CO})$ and water vapour $\left(\mathrm{H}_{2} \mathrm{O}\right)$ using off-axis integrated cavity output spectroscopy (ICOS). Test results and environmental data for $\mathrm{N}_{2} \mathrm{O}$ are reported in this study. The analyser was connected to a $1.7 \mathrm{~L}$ percolating packed glass bed equilibrator as described by Cooper et al. (1998). The analyser's internal membrane pump was used to circulate the gas phase through the equilibrator. Water was pumped through the equilibrator at a flow rate of $1.8 \mathrm{~L} \mathrm{~min}^{-1}$. Two 4-port 2-position valves (Vici) allowed for fast switching between the equilibrator headspace and a 6-port multiposition valve (Vici), connecting to other gas lines e.g. atmospheric air and references (Fig. 1). A similar setup has been described by Gülzow et al. (2011) for dissolved $\mathrm{CO}_{2}$ and $\mathrm{CH}_{4}$ measurements using an ICOS analyser and by Becker et al. (2012) for measurements of $\delta^{13} \mathrm{C}\left(\mathrm{CO}_{2}\right)$

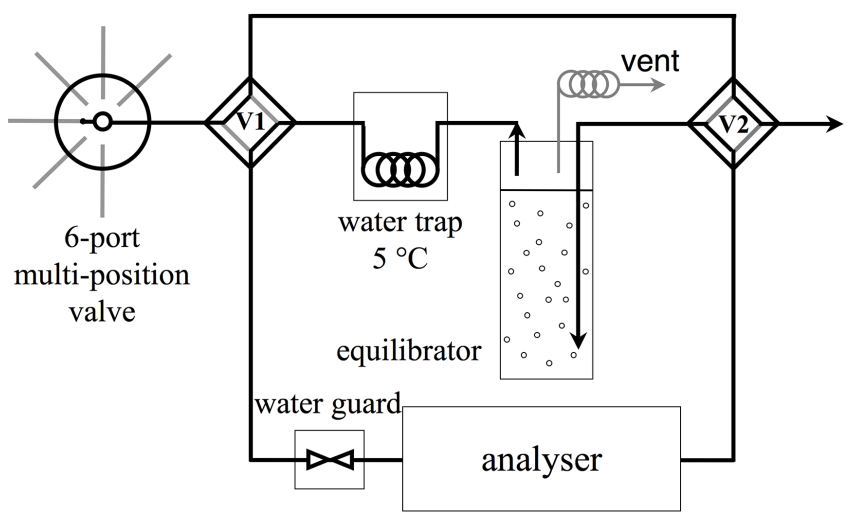

Figure 1. Setup for laboratory tests. V1 and V2: 4-port 2-position valves. Arrows indicate gas flow through the equilibrator. The vent is a $3 \mathrm{~m}$ long coiled $1 / 8 \mathrm{in}$. plastic tube to allow for volume and pressure changes of the equilibrator headspace due to variations in gas tension.

and $f \mathrm{CO}_{2}$ using continuous wave cavity ring-down spectroscopy.

A water trap was installed downstream of the equilibrator to reduce the amount of water vapour in the headspace gas. The trap consisted of a thermoelectric cool box (T08 DC, Mobicool), held at $5{ }^{\circ} \mathrm{C}$, and a miniature filter with manual drain (Norgren) to collect the condensing water. A custombuilt safety valve ("water guard") was installed upstream of the analyser as an additional protection against water entering the measurement cell. The water guard consists of a stainless steel tee (Swagelok) with electrodes and a solenoid valve downstream of the sensor. Water in the gas line closes the electric circuit in the water guard, triggering the closure of the valve and cutting off the gas supply to the analyser. This is really just a safety precaution as the "water-guard" was neither triggered during the laboratory tests, nor at sea. The instrument's water vapour measurements are used by the software to calculate $\mathrm{N}_{2} \mathrm{O}$ dry mole fractions (Eq. 1). $x\left(\mathrm{~N}_{2} \mathrm{O}\right)$ is the $\mathrm{N}_{2} \mathrm{O}$ dry mole fraction, $x_{\text {meas }}\left(\mathrm{N}_{2} \mathrm{O}\right)$ and $x_{\text {meas }}\left(\mathrm{H}_{2} \mathrm{O}\right)$ are the measured $\mathrm{N}_{2} \mathrm{O}$ and $\mathrm{H}_{2} \mathrm{O}$ mole fractions:

$x\left(\mathrm{~N}_{2} \mathrm{O}\right)=\frac{x_{\text {meas }}\left(\mathrm{N}_{2} \mathrm{O}\right)}{1-x_{\text {meas }}\left(\mathrm{H}_{2} \mathrm{O}\right)}$.

Furthermore, line broadening due to changing water vapour concentrations is accounted for by the instrument's software. The instrument is factory calibrated for $\mathrm{H}_{2} \mathrm{O}$ using a dewpoint generator. In order to validate this water vapour correction, measurements of dry air were compared to calculated values for the dry mole fraction of humidified air. A cylinder with dry air was connected to the analyser via the multiposition valve. The gas line from the cylinder was split with one line going directly to the valve and the other one passing first through the water-filled cold trap to humidify the air. $\mathrm{H}_{2} \mathrm{O}$ mole fractions were between 1 and $1.4 \%$ for the humidified gas and below the analyser's detection limit 
(around $0.2 \%$ for $\mathrm{H}_{2} \mathrm{O}$ ) for dry gas. The calculated dry mole fraction of the humidified gas was compared to that of the dry gas.

In addition, to test for analyser variability and drift, dry cylinder gas was measured for $24 \mathrm{~h}$. To test for leaks within the analyser, laboratory air $\left(325 \mathrm{nmol} \mathrm{mol}^{-1}\right.$ dry mole fraction, uncalibrated) and zero grade air $\left(\mathrm{O}_{2}\right.$ and $\mathrm{N}_{2}$, $\sim 84 \mathrm{nmol} \mathrm{mol}^{-1} \mathrm{~N}_{2} \mathrm{O}$ dry mole fraction uncalibrated, BOC) were mixed in a sample loop to obtain lower mole fractions than in ambient air. The mixtures with $215.1 \mathrm{nmol} \mathrm{mol}^{-1}$ $\mathrm{N}_{2} \mathrm{O}$ were recirculated through the analyser for 12 and $21 \mathrm{~min}$. Any leaks are expected to be noticed as an increase in $\mathrm{N}_{2} \mathrm{O}$ mole fractions caused by ambient air. The valve board was leak-checked separately by pressurising the gas lines of the equilibrator loop with compressed air to just below $120 \mathrm{kPa}$. The equilibrator itself was bypassed during this test because it communicates with the atmosphere at three points: the water inlet, the water outlet and the pressure vent. As the LGR analyser keeps the pressure in the measurement cell constant at $11 \mathrm{kPa}$ and the measurement range of the builtin pressure sensor ends at $22 \mathrm{kPa}$, a Li-Cor $\mathrm{CO}_{2}$ instrument with built-in pressure gauge was used instead for monitoring pressure changes over time.

The response time of the coupled system of the ICOS (integrated cavity output spectroscopy) analyser and equilibrator was characterised in further laboratory tests. The equilibrator time constant $\tau$, i.e. the time during which a concentration difference between the gas- and the water phase declines to $1 / e(36.8 \%)$ with regard to the start value, was determined as described in Gülzow et al. (2011). $\tau$ was only evaluated for $\mathrm{N}_{2} \mathrm{O}$ as $\mathrm{CO}$ background concentrations were too variable in the laboratory where tests took place. Two $100 \mathrm{~L}$ reservoirs, open to the atmosphere, were filled with fresh water from the tap, which is supersaturated in $\mathrm{N}_{2} \mathrm{O}$. Mole fractions between 694 and $1065 \mathrm{nmol} \mathrm{mol}^{-1}$ were measured in the equilibrator headspace during five experiments with supersaturated water. One of the reservoirs was then equilibrated with ambient air by recirculation; the other was kept at elevated $\mathrm{N}_{2} \mathrm{O}$ concentrations. For the experiments, the water was pumped through the equilibrator from the bottom of the reservoirs at a flow rate of $1.8 \mathrm{~L} \mathrm{~min}^{-1}$, starting with the equilibrated reservoir, and then changing to water with high $\mathrm{N}_{2} \mathrm{O}$ concentrations. After the measured dry mole fraction reached a plateau $\left(x_{\max }\right)$, water in equilibrium with ambient air was pumped through the equilibrator. $\tau$ was then calculated as described in Gülzow et al. (2011), recording the decay of $\mathrm{N}_{2} \mathrm{O}$ dry mole fractions $\left(x_{t}\right)$ back to ambient values $\left(x_{\min }\right)$. The observed $x_{t}$ values (Fig. 2) were fitted to an exponential equation:

$x_{t}=x_{\min }+\left(x_{\max }-x_{\min }\right) e^{-\frac{t}{\tau}}$.

By rearranging Eq. (2), $\tau$ can be inferred from the slope of a linear regression of $-\ln \left[\left(x_{t}-x_{\min }\right) /\left(x_{\max }-x_{\min }\right)\right]$ against time.

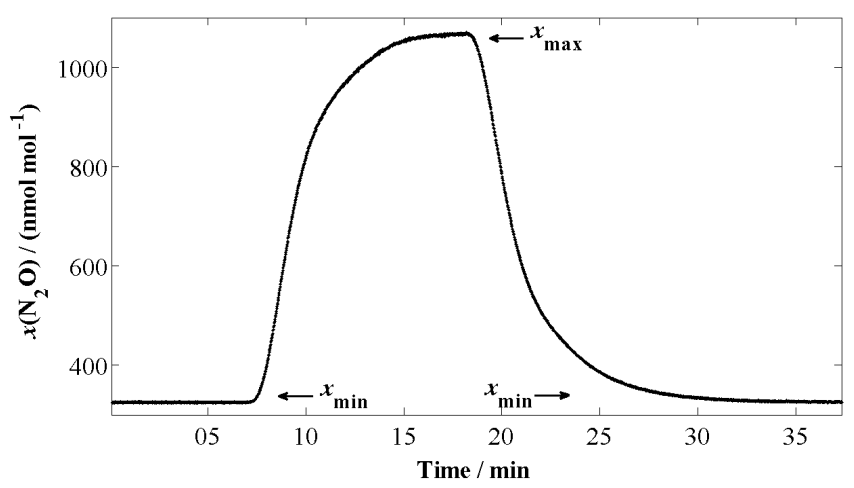

Figure 2. $\mathrm{N}_{2} \mathrm{O}$ concentrations during the step experiment for determination of $\tau$. Equilibrated water flowing through the equilibrator is replaced with water containing higher $\mathrm{N}_{2} \mathrm{O}$ concentrations.

Initially, it was attempted to use the analyser in combination with a semi-permeable membrane (Membrana, MiniModule). For this purpose, the gas flow through the cavity was reduced to $100 \mathrm{~mL} \mathrm{~min}^{-1}(293 \mathrm{~K}, 100 \mathrm{kPa}$ ) by inserting a needle valve between the internal diaphragm pump and a check valve downstream of the measurement cell. The yield of dissolved gases extracted over the membrane was too low to sustain the analyser's operating pressure in the measurement cell. Therefore, an equilibrator was used instead of the semi-permeable membrane. As the reduced gas flow did not lead to problems with the equilibrator setup, the valve was retained during the first field test (see Sect. 2.2). Without the throttle valve, the flow rate increased to approximately $400 \mathrm{~mL} \mathrm{~min}^{-1}(293 \mathrm{~K}, 100 \mathrm{kPa})$. The time constant $\tau$ was determined for both headspace flow rates.

\subsection{Field deployment of equilibrator and ICOS analyser}

The $\mathrm{N}_{2} \mathrm{O}$ analyser was tested at sea during cruise AMT20 of the Atlantic Meridional Transect project from Southampton, UK, to Punta Arenas, Chile (12 October to 25 November 2010), on board RRS James Cook. Figure 3 shows the setup for underway measurements during the cruise, Fig. 4 the cruise track.

The equilibrator was connected to the ship's pumped underway seawater supply, drawing water from a depth of approximately $5 \mathrm{~m}$. Filters (Vacu-guard, part number 67225000 , Wheaton) were inserted at the gas inlet and outlet of the equilibrator to protect pump and measurement cells of the analyser from seawater. Temperatures in the equilibrator were measured with two Pt-100 temperature probes (Omega Engineering Limited), calibrated against a mercury reference thermometer with an accuracy of $0.06^{\circ} \mathrm{C}$. This measurement uncertainty leads to a $0.17 \%$ (at $30^{\circ} \mathrm{C}$ ) to $0.25 \%$ (at $0{ }^{\circ} \mathrm{C}$ ) uncertainty in the derived surface seawater concentrations. For future studies, a temperature calibration to better than $0.01{ }^{\circ} \mathrm{C}$ is recommended to further reduce measurement 


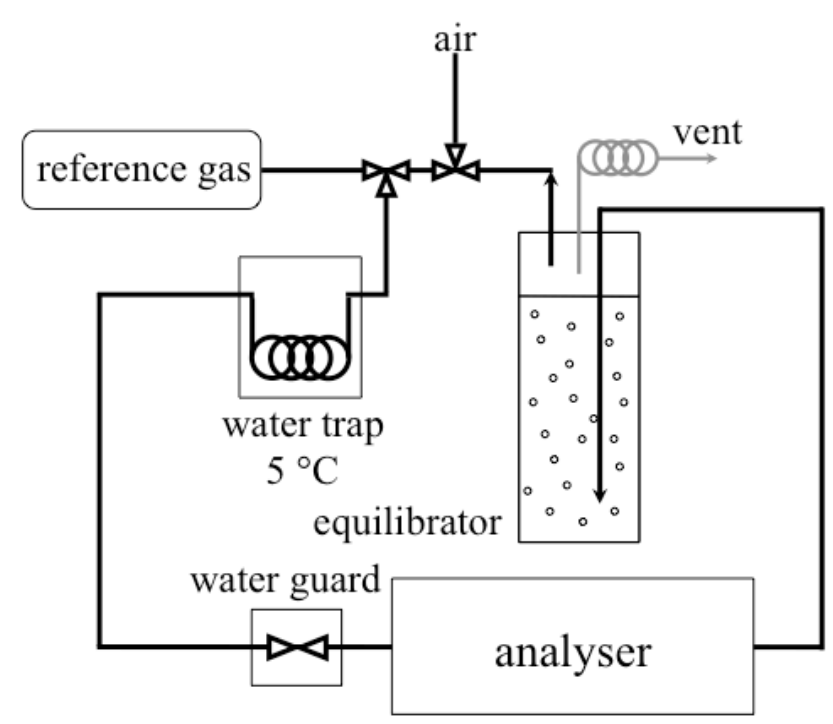

Figure 3. Underway setup for field deployment during AMT 20. Two manual 3-port valves allow switching between measurements of the equilibrator headspace, marine air, and dry air.

uncertainties. The water flow through the equilibrator was set to approximately $1.8 \mathrm{~L} \mathrm{~min}^{-1}$ via a valve. Flow was verified by regular (at least hourly) monitoring of the constancy of the water level in the equilibrator and manual measurement of the rate of water flow from the bottom of the equilibrator. Flow stagnation was observed on four occasions during the cruise, and attributed to pressure fluctuations in the underway system caused by other users. Affected data were removed from the results presented here, as well as the first $15 \mathrm{~min}$ after readjustment of the water flow. For subsequent field deployments, a flow restrictor will be used to stabilise the pumped seawater supply to the equilibrator. Two three-way valves (part number SS-41GXS2, Swagelok) allowed changing between sample gas stream from the equilibrator and marine air, drawn from the ship's bow (Fig. 3). Dried air with $323.7 \mathrm{nmol} \mathrm{mol}^{-1} \mathrm{~N}_{2} \mathrm{O}$ was used as a working reference, calibrated against IMECC/NOAA (Infrastructure for the Measurement of the European Carbon Cycle/National Oceanic and Atmospheric Administration) primary standards. Every $8 \mathrm{~h}$, the analyser was calibrated by switching from equilibrator headspace to the reference gas and then marine air for $20 \mathrm{~min}$ each. This was followed by another reference measurement after $40 \mathrm{~min}$ to assess short-time drift. Only the last $5 \mathrm{~min}$ of each measurement were analysed to allow for complete flushing of the measurement cell. Correspondingly, the first $15 \mathrm{~min}$ after switching back to the equilibrator headspace or to air measurements were not used for evaluation to allow for flushing of air and reference gas residuals from the measurement cavity and equilibrator.

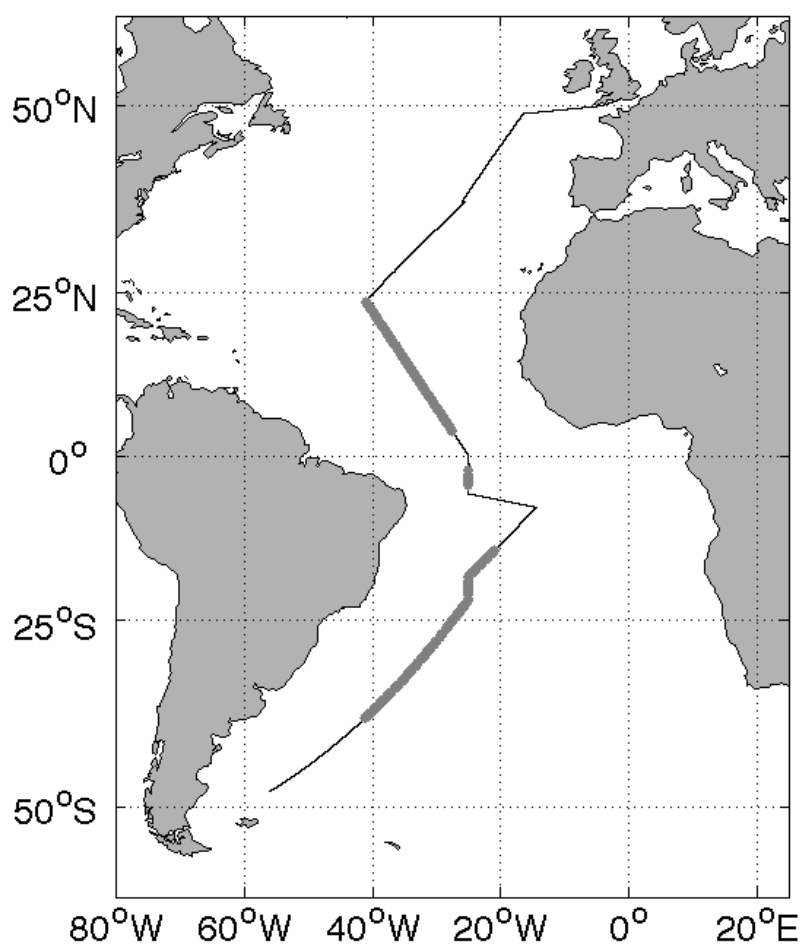

Figure 4. Cruise track of AMT20. Thick grey lines indicate positions of measurements with the $\mathrm{N}_{2} \mathrm{O}$ analyser.

$\mathrm{N}_{2} \mathrm{O}$ concentrations $(c)$ were calculated from dry mole fractions $(x)$ using the solubility function $F$ at equilibrator temperature $T_{\mathrm{eq}}$ (Weiss and Price, 1980):

$c=x F\left(T_{\mathrm{eq}}, S\right) p_{\mathrm{eq}}$,

where $T_{\mathrm{eq}}$ and $p_{\mathrm{eq}}$ are equilibrator temperature and pressure (assumed to be equal to ambient atmospheric pressure, $p_{\text {air }}$ at sea level and assuming $100 \%$ relative humidity) and $S$ is salinity. Note that the unit of $F$ in Eq. (8) of Weiss and Price (1980) $\left(\mathrm{mol} \mathrm{kg}^{-1}\right.$ or $\left.\mathrm{mol} \mathrm{L}^{-1}\right)$ is inconsistent with the unit of $F$ in their tables $\left(\mathrm{mol} \mathrm{kg}^{-1} \mathrm{~atm}^{-1}\right.$ or $\mathrm{mol} \mathrm{L}^{-1} \mathrm{~atm}^{-1}$ ). We use $F$ as parameterised by Eq. (13) in Weiss and Price (1980), multiplied by the equilibrator pressure and the dry mole fraction, to derive $c$.

Seawater saturations $(s)$ were based on equilibrium values for measured atmospheric mole fractions $x_{\text {air }}$ and mole fractions in seawater, corrected for temperature differences between equilibrator and seawater intake $\left(T_{\text {in }}\right)$ :

$s=\frac{x F\left(T_{\mathrm{eq}}, S\right)}{x_{\mathrm{air}} F\left(T_{\mathrm{in}}, S\right)}$.

The air-sea flux $(\Phi)$ was calculated from the gas transfer coefficient $\left(k_{\mathrm{w}}\right)$ and the difference between $\mathrm{N}_{2} \mathrm{O}$ concentrations in seawater $c$ and air equilibrium concentrations $\left(c_{\text {air }}\right)$ :

$\Phi=k_{\mathrm{w}}\left(c-c_{\text {air }}\right)=k_{\mathrm{w}}\left[c-x_{\text {air }} F\left(T_{\text {in }}, S\right) p_{\text {air }}\right]$. 
A water vapour correction is not required because it is already included in the parametrisation of $F$ (Weiss and Price, 1980). $F$ requires the equilibrator pressure to be close to $p^{\circ}=1 \mathrm{~atm}=1013.25 \mathrm{hPa}$. The correction term for deviations of the equilibrator pressure $p_{\mathrm{eq}}$ from $p^{\circ}$ is given in Eq. 6 and is between 0.9998 at $p_{\text {eq }}=970 \mathrm{hPa}$ and 1.0002 at $p_{\mathrm{eq}}=1050 \mathrm{hPa}$ for temperatures between -2 and $30^{\circ} \mathrm{C}$. This correction of less than $\pm 0.02 \%$ is negligible.

$$
\begin{aligned}
& c\left(\mathrm{~N}_{2} \mathrm{O}\right)= \\
& x\left(\mathrm{~N}_{2} \mathrm{O}\right) F\left(\mathrm{~N}_{2} \mathrm{O}, T_{\mathrm{eq}}, S\right) p_{\mathrm{eq}} \frac{1-\frac{p_{\mathrm{vap}}\left(\mathrm{H}_{2} \mathrm{O}, T_{\mathrm{eq}}, S\right)}{p_{\mathrm{eq}}}}{1-\frac{p_{\mathrm{vap}}\left(\mathrm{H}_{2} \mathrm{O}, T_{\mathrm{eq}}, S\right)}{p^{\circ}}}
\end{aligned}
$$

$k_{\mathrm{W}}$ was calculated using the parameterisation of Nightingale (2000) and converted to units of $\mathrm{m} \mathrm{d}^{-1}$, where $u$ is wind speed at $10 \mathrm{~m}$ above sea level (Eq. 7).

$$
\begin{aligned}
& \frac{k_{\mathrm{W}}}{\mathrm{md}^{-1}}= \\
& 0.24\left[0.222\left(\frac{u}{\mathrm{~ms}^{-1}}\right)^{2}+0.333 \frac{u}{\mathrm{~ms}^{-1}}\right]\left(\frac{S c}{600}\right)^{-0.5}
\end{aligned}
$$

This relationship shows an intermediate dependence on wind speed compared to the other frequently used parameterisations of Liss and Merlivat (1986) and Wanninkhof (1992), and gives fluxes in very good agreement (on average $0.004 \mu \mathrm{mol} \mathrm{m} \mathrm{m}^{-2} \mathrm{~d}^{-1}$ difference) with the parameterisation of Sweeney et al. (2007). $k_{\mathrm{w}}$ was adjusted for $\mathrm{N}_{2} \mathrm{O}$ with the Schmidt number $S c$ calculated following Wanninkhof (1992). The wind speed at $10 \mathrm{~m}$ height was taken from the 6-hourly operational analysis data set of the European Centre for Medium-Range Weather Forecasts (ECMWF) and interpolated to the time and position of the respective measurement (download from BADC at http://badc.nerc.ac.uk/view/badc.nerc.ac.uk_ _ATOM_dataent_ECMWF-OP).

Instantaneous values for $k_{\mathrm{w}}$ and $\Phi$ were compared to those using 30-day wind-speed-weighted averages to give a more robust estimate of gas exchange in light of variable wind speed over time (Reuer et al., 2007). The calculation takes into account that wind speed varies over time at any given location and weighs it appropriately according to mixed layer depth, assuming a constant $\mathrm{N}_{2} \mathrm{O}$ production/influx rate in the mixed layer. Differences between both estimates of sea-air exchange were small. In the following, we discuss only instantaneous fluxes for consistency with previous studies of $\mathrm{N}_{2} \mathrm{O}$ air-sea exchange (Fig. 5).

\subsection{GC-MS measurements of discrete samples}

During a subsequent cruise to the Weddell Sea on board RRS James Clark Ross from 20 January to 2 February 2012 (JR255A), rosette water samples were collected. These were analysed for $\mathrm{N}_{2} \mathrm{O}$ concentrations using purge-and-trap gas

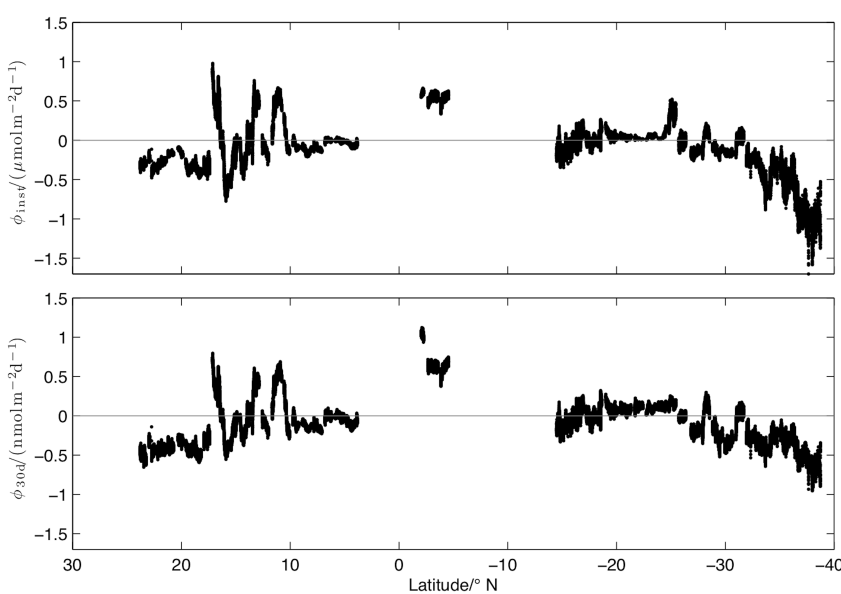

Figure 5. Comparison of $\mathrm{N}_{2} \mathrm{O}$ flux calculated from instantaneous (top panel) and 30-day-averaged wind speeds (bottom panel).

chromatography-mass spectrometry (GC-MS), with the data and comparisons to simultaneous equilibrator ICOS measurements presented in Sect. 3.2. The majority of the sea surface measurements on this cruise will be presented elsewhere.

Rosette seawater samples for isotope analysis were collected in $500 \mathrm{~mL}$ (nominal value) serum bottles (Wheaton). Triplicate samples were taken immediately after recovery of the CTD (conductivity, temperature and depth sensor) and were allowed to overflow at least three times the bottle's volume. Sample bottles were closed with butyl stoppers and aluminium crimp seals and poisoned with $1 \mathrm{~mL}$ saturated mercuric chloride solution. Of the sample, $1 \mathrm{~mL}$ was replaced with CP grade helium (BOC) to reduce the risk of leaks due to temperature driven volume changes of the water during transport and storage. The setup of the GC-MS follows McIlvin and Casciotti (2010). Samples are loaded manually; dissolved gases are quantitatively extracted with a helium purge stream and trapped with liquid nitrogen. Water vapour in the gas stream is removed with a Nafion dryer (Perma Pure), $\mathrm{CO}_{2}$ is trapped on Carbosorb (Merck). The sample is then injected into a continuous-flow GC-MS system. Late eluting substances are removed with a precolumn as described in Röckmann et al. (2003) before $\mathrm{N}_{2} \mathrm{O}$ is separated from residual $\mathrm{CO}_{2}$ on the PoraPlot $\mathrm{Q}$ analytical column. The sample enters the mass spectrometer (Thermo Scientific, MAT 253) via an open split and is analysed for $m / z 44,45$ and 46. The $\mathrm{N}_{2} \mathrm{O}$ amount in the sample can be calculated from the peak area with a precision of $2 \%$ (based on analysis of replicates) and the sample volume, which is determined by sample weight, water temperature and salinity, with a precision of $0.02 \%$. The overall precision of $2 \%$ is comparable to the $1.8 \%$ concentration uncertainty achieved for GC-ECD measurements by Walter et al. (2006) and 2.6\% for GC-MS measurements by McIlvin and Casciotti (2010). 


\section{Results and discussion}

\subsection{Laboratory tests}

To improve the precision of individual data points retained for further analysis, $10 \mathrm{~s}$ averages were calculated from measurements at $1 \mathrm{~Hz}$. Since the headspace gas was in contact with the water phase in the equilibrator, water vapour concentrations were high. The cold trap only removed water to a dew point of $5{ }^{\circ} \mathrm{C}$, corresponding to about $8.7 \mathrm{mmol} \mathrm{mol}^{-1}$. Correction from measured values to dry mole fractions is therefore required for the evaluation of dissolved $\mathrm{N}_{2} \mathrm{O}$ concentrations in seawater.

Compressed air directly from the cylinder had a measured $\mathrm{N}_{2} \mathrm{O}$ mole fraction of $(332.7 \pm 0.2) \mathrm{nmol} \mathrm{mol}^{-1}$, while $\mathrm{H}_{2} \mathrm{O}$ mole fractions were below the detection limit of $2 \mathrm{mmol} \mathrm{mol}^{-1}$. The measured $\mathrm{N}_{2} \mathrm{O}$ mole fraction in humidified air with $10.6 \mathrm{mmol} \mathrm{mol}^{-1} \mathrm{H}_{2} \mathrm{O}$ was ( $329.7 \pm 0.2) \mathrm{nmol} \mathrm{mol}^{-1}$. Since the $\mathrm{H}_{2} \mathrm{O}$ mole fraction in compressed air was below the detection limit of $2 \mathrm{mmol} \mathrm{mol}^{-1}$, we assume it to be in the range from 0 to $2 \mathrm{mmol} \mathrm{mol}^{-1}$. The corresponding dry mole fraction of compressed air is therefore $\left(332.7_{-0.2}^{+0.8}\right) \mathrm{nmol} \mathrm{mol}{ }^{-1}$, where the error estimate in the positive direction corresponds to a $\mathrm{H}_{2} \mathrm{O}$ mole fraction of $2 \mathrm{mmol} \mathrm{mol}^{-1}$, that in the negative direction corresponds to the statistical uncertainty and $\mathrm{H}_{2} \mathrm{O}$ mole fraction of 0 . The calculated dry mole fraction of humidified air was $(333.1 \pm 0.2) \mathrm{nmol} \mathrm{mol}^{-1}$. This value is within measurement uncertainties of the corrected mole fraction of compressed air directly from the cylinder. The $\mathrm{H}_{2} \mathrm{O}$ vapour dilution correction is considered to be sufficient; no further corrections for line broadening were applied.

The stability of the analyser at low $\mathrm{N}_{2} \mathrm{O}$ mole fractions was assessed by measuring a gas cylinder over $24 \mathrm{~h}$. The standard deviation was $0.2 \mathrm{nmol} \mathrm{mol}^{-1}$ for a mean $\mathrm{N}_{2} \mathrm{O}$ mole fraction on $48.7 \mathrm{nmol} \mathrm{mol}^{-1}$; slightly better than the $5 \mathrm{~h}$ stability of $\pm 0.6 \mathrm{nmol} \mathrm{mol}^{-1}$ reported by Arévalo-Martínez et al. (2013). Minimum and maximum values measured during this period were 48.2 and $49.4 \mathrm{nmol} \mathrm{mol}^{-1}$, respectively. An Allan variance test for this low $\mathrm{N}_{2} \mathrm{O}$ mole fraction showed a minimum Allan deviation of $(25 \pm 1) \mathrm{pmol} \mathrm{mol}^{-1}$ for an integration interval of 90-180 s (1.5-3 min).

An Allan variance test for a reference gas with an $\mathrm{N}_{2} \mathrm{O}$ mole fraction closer to ambient values $\left(299 \mathrm{nmol} \mathrm{mol}^{-1}\right)$ gave a minimum Allan deviation of $(33 \pm 6) \mathrm{pmol} \mathrm{mol}^{-1}$ for an integration interval of 80-105 s. These results are comparable to the value of $37 \mathrm{pmol} \mathrm{mol}^{-1}$ over 2 min reported by Arévalo-Martínez et al. (2013).

The highest observed increase of $\mathrm{N}_{2} \mathrm{O}$ mole fractions during the two leak tests for the LGR analyser was $0.024 \mathrm{nmol} \mathrm{mol}^{-1} \mathrm{~min}^{-1}$. The gas volume of the $400 \mathrm{~mL}$ measurements cell at a pressure of $11 \mathrm{kPa}$ corresponds to $40 \mathrm{~mL}$ while the tubing of the circular gas path for this test is assumed to be at atmospheric pressure, resulting in a volume of approximately $40 \mathrm{~mL}$. The total gas volume during

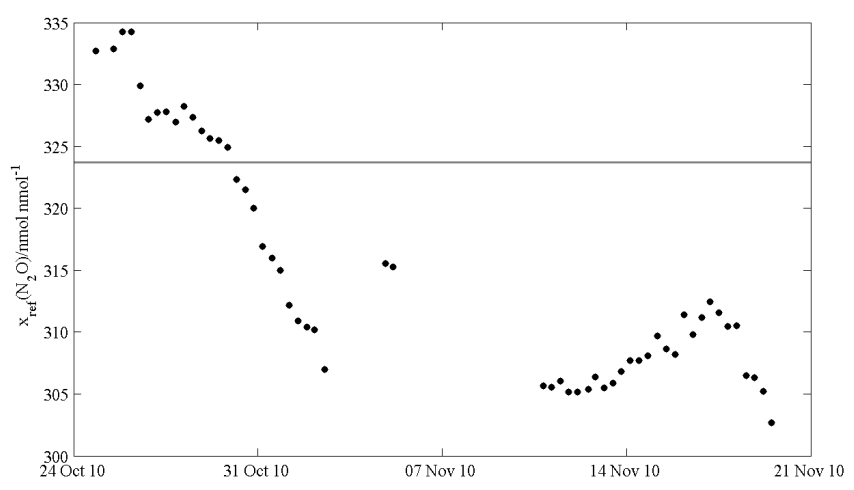

Figure 6. Measured values for the reference gas during the transect. Nominal value of $323.7 \mathrm{nmol} \mathrm{mol}^{-1}$ indicated by grey line.

the test is therefore $80 \mathrm{~mL}$. The leak rate was calculated as the increase in $\mathrm{N}_{2} \mathrm{O}$ concentrations, divided by the difference between background $\mathrm{N}_{2} \mathrm{O}$ and circulating gas mixture and multiplied by the total gas volume. The resulting leak rate for the $\mathrm{N}_{2} \mathrm{O}$ analyser used for recirculating air, e.g. through an equilibrator, is $0.017 \mathrm{~mL} \mathrm{~min}^{-1}$ or $0.29 \times 10^{-3} \mathrm{~mL} \mathrm{~s}^{-1}$. This leak rate is likely to be due to the pump head (on the order of $10^{-3} \mathrm{~mL} \mathrm{~s}^{-1}$, KNF Neuberger (UK) Ltd., personal communication, 2013). Pressure in the valve board was stable over $10 \mathrm{~min}$ at $119731 \pm 0.006 \mathrm{~Pa}$ as recorded by the $\mathrm{Li}$ Cor's pressure gauge, indicating the absence of leaks.

The response time of the coupled analyser-equilibrator system to concentration changes in the water phase is described by the equilibration time constant $\tau$, which was determined for conditions experienced during field deployment. For a gas flow of $400 \mathrm{~mL} \mathrm{~min}^{-1}$ through the measurement cell, $\tau$ equalled $(142 \pm 1) \mathrm{s}$ for $\mathrm{N}_{2} \mathrm{O}(n=5)$. The $95 \%$ relaxation time (i.e. $3 \tau$ ) is therefore about $7 \mathrm{~min}$. Reducing the gas flow to $100 \mathrm{~mL} \mathrm{~min}^{-1}$ increased $\tau$ to $(203 \pm 1) \mathrm{s}(n=3)$, without changing the measured mole fraction. In the limit where the water flow rate is much higher than the gas exchange rate, the value for $\tau$ depends on the transfer coefficient $k$ (Rafelski et al., 2012). Presumably, at the higher gas flow rate enhanced turbulence increased the efficiency of gas transfer between water and gas. Therefore, the needle valve will be removed during future deployments to reduce delays in the system's response to changing $\mathrm{N}_{2} \mathrm{O}$ concentrations in the environment. Values for $\tau$ are similar to those reported for $\mathrm{N}_{2} \mathrm{O}$ of $180 \mathrm{~s}$ by Arévalo-Martínez et al. (2013), using a similar measurement setup.

\subsection{Precision and comparison with GC-MS}

Under field conditions during AMT20, the difference between two subsequent calibration measurements, spaced $40 \mathrm{~min}$ apart, was on average $0.2 \mathrm{nmol} \mathrm{mol}^{-1}$ or better. This is comparable to the short-term stability of $0.2 \mathrm{nmol} \mathrm{mol}^{-1}$ over 3 min reported by Arévalo-Martínez et al. (2013). During AMT20, substantial long-term drift was encountered 


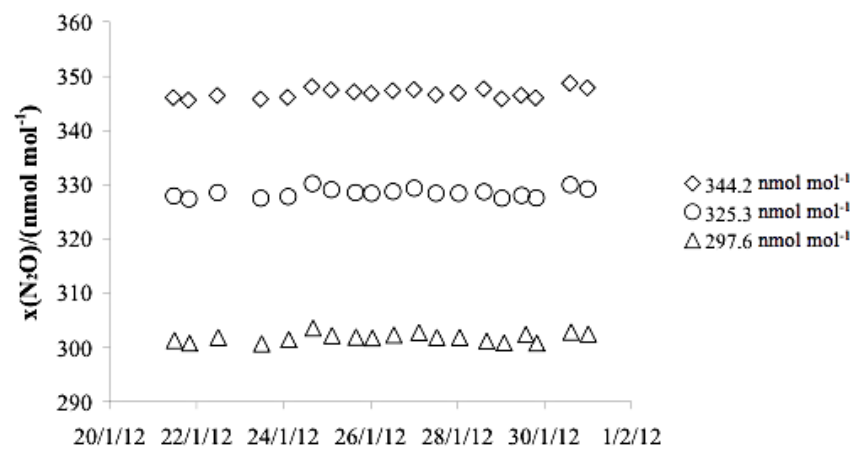

Figure 7. $\mathrm{N}_{2} \mathrm{O}$ mole fractions for the three reference gases used during JR255A over time.

(Fig. 6). It was assumed that instrument drift was linear between reference gas measurements, and the linear dynamic range of the analyser passed through the origin. As only one reference gas was used during AMT20, this could not be investigated any further. During cruise JR255A three reference gases were used (Fig. 7). The stability of the dry mole fractions of these three gases over the length of the field campaign was $0.9 \mathrm{nmol} \mathrm{mol}^{-1}(0.3 \%)$ or better $(n=19)$. The slope for the dynamic range was 1.04 and the $y$ axis offset $-15 \mathrm{nmol} \mathrm{mol}^{-1}$. This would have a negligible influence for the range of $\mathrm{N}_{2} \mathrm{O}$ mole fractions encountered during AMT20 due to their small variations around the nominal value of the reference gas $\left(323.7 \mathrm{nmol} \mathrm{mol}^{-1}\right)$ : at the lower end (near $97 \%$ saturation), it would lead to positive bias of $0.5 \mathrm{nmol} \mathrm{mol}^{-1}$ (or less than $0.2 \%$ ); at the upper end (near $103 \%$ saturation), it would lead to a negative bias of $-0.4 \mathrm{nmol} \mathrm{mol}^{-1}$. Therefore, the reference gas measurements could be used to fully correct air and equilibrator measurements for analyser offset and drift, using linear interpolation between calibrations (see also Fig. 8). The instrument drift was caused by a gradual change of the laser tuning (R. Provencal, personal communication, 2010). The laser was replaced after AMT20 and the analyser has been stable since. The use of three reference gases, as done for JR255A, is recommended to improve the calibration of analyser data during future field deployments.

Measurements of atmospheric $\mathrm{N}_{2} \mathrm{O}$ mole fractions during AMT20 and JR255A were used for comparison with data of selected Advanced Global Atmospheric Gases Experiment (AGAGE) stations (Prinn et al., 2000). Dry mole fractions were corrected for instrument drift and offset with the calibration measurements. During AMT20, mole fractions of $\mathrm{N}_{2} \mathrm{O}$ measured in marine background air were $(323.2 \pm 0.5) \mathrm{nmol} \mathrm{mol}^{-1}$ throughout the cruise. An interhemispheric difference of slightly less than $1 \mathrm{nmol} \mathrm{mol}^{-1}$ was expected (Butler et al., 1989; Rhee et al., 2009), but did not show in the data. This small difference might have not been captured due to the analyser drift described above, and the small number of atmospheric measurements $(n=$

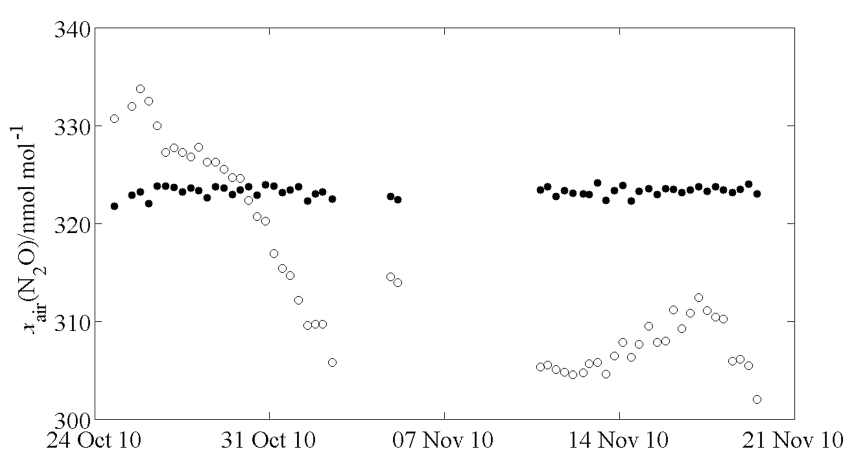

Figure 8. $\mathrm{N}_{2} \mathrm{O}$ mole fractions measured during AMT20 in tropospheric air. Open circles are raw measurement values before drift and offset corrections, filled circles are fully corrected values.

26 in the Northern Hemisphere and $n=29$ in the Southern Hemisphere). This undersampling in combination with natural variability (e.g. seasonality, source of air masses) could account for the absence of the expected interhemispheric gradient of $(1.2 \pm 0.8) \mathrm{nmol} \mathrm{mol}^{-1}$ in this data set. During future measurement campaigns, more frequent atmospheric air measurements or a dedicated analyser may be required to reliably detect the interhemispheric $\mathrm{N}_{2} \mathrm{O}$ mole fraction gradient. Nevertheless, the measured atmospheric mole fractions of (323.2 \pm 0.5$) \mathrm{nmol} \mathrm{mol}^{-1}$ agree within measurement uncertainties with mean values for October and November of the AGAGE stations Mace Head for the Northern Hemisphere $\left((324.1 \pm 0.7) \mathrm{nmol} \mathrm{mol}^{-1}\right)$ and Cape Grim for the Southern Hemisphere $\left((322.9 \pm 0.3) \mathrm{nmol} \mathrm{mol}^{-1}\right.$, data from http://agage.eas.gatech.edu/data_archive) (Fig. 6). During JR255A, measured $\mathrm{N}_{2} \mathrm{O}$ mole fractions in air were $(324.0 \pm 0.7) \mathrm{nmol} \mathrm{mol}^{-1}(n=11)$, which is consistent with the value of $(323.9 \pm 0.5) \mathrm{nmol} \mathrm{mol}^{-1}$ measured at Cape Grim in January 2012. Neither during AMT20 nor during JR255A, were measurements of atmospheric $\mathrm{N}_{2} \mathrm{O}$ mole fractions influenced by wind direction.

The equilibrator type used for seawater measurements is described in Cooper et al. (1998). The authors found no systematic differences for $\mathrm{CO}_{2}$ measurements made with this equilibrator compared to shower-head equilibrators. As the solubility characteristics of $\mathrm{N}_{2} \mathrm{O}$ are similar to $\mathrm{CO}_{2}$ (Weiss and Price, 1980), no bias is expected to be introduced by using this equilibrator type and the equilibrator efficiency should be similar. Correcting equilibrator measurements for instrument drift and offset using the reference gas measurements resulted in a precision of $0.2 \mathrm{nmol} \mathrm{mol}^{-1}$ over a $5 \mathrm{~min}$ average.

Table 1 shows a comparison between equilibrator measurements and GC-MS analyses of discrete water samples during cruise JR255A. Concentrations measured with GCMS were $(1.3 \pm 0.9) \%$ higher than those obtained with the LGR $\mathrm{N}_{2} \mathrm{O}$ analyser. Although the values match within the $2 \%$ measurement uncertainty associated with the GC-MS 
Table 1. Comparison between ICOS and GC-MS measurements during JR255A. Sampling time (GMT, Greenwich Mean Time) and position for the three depth casts overlapping with analyser measurements. $c_{\text {eq }}$ is the equilibrium concentration for atmospheric $\mathrm{N}_{2} \mathrm{O}$ based on sea surface temperature $\left(\theta_{0}\right)$, salinity $\left(S_{0}\right)$ and atmospheric pressure $\left(p_{\text {atm }}\right)$.

\begin{tabular}{lrrrrrrrr}
\hline $\begin{array}{l}\text { Date \& } \\
\text { time }\end{array}$ & $\begin{array}{r}\text { Latitude/ } \\
{ }^{\circ} \mathrm{N}\end{array}$ & $\begin{array}{r}\text { Longitude/ } \\
{ }^{\circ} \mathrm{E}\end{array}$ & $\begin{array}{r}\theta_{0} / \\
{ }^{\circ} \mathrm{C}\end{array}$ & $S_{0}$ & $\begin{array}{r}p_{\text {atm }} / \\
\mathrm{kPa}\end{array}$ & $\begin{array}{r}\left.c\left(\mathrm{~N}_{2} \mathrm{O}, \mathrm{LGR}\right) /\right) \\
\left(\mathrm{nmol} \mathrm{L}{ }^{-1}\right)\end{array}$ & $\begin{array}{r}c\left(\mathrm{~N}_{2} \mathrm{O}, \mathrm{GC}-\mathrm{MS}\right) / \\
\left(\mathrm{nmol} \mathrm{L}^{-1}\right)\end{array}$ & $\begin{array}{r}c_{\text {eq }}\left(\theta_{0}, S_{0} p_{\text {atm }}\right) / \\
\left(\mathrm{nmol} \mathrm{L}^{-1}\right)\end{array}$ \\
\hline $23 / 01 / 2012,19: 53$ & -63.4 & -53.0 & 0.56 & 34.31 & 101 & $15.44 \pm 0.02$ & $15.77 \pm 0.3$ & $14.90 \pm 0.2$ \\
$24 / 01 / 2012,03: 48$ & -63.5 & -52.1 & 0.24 & 34.02 & 101 & $15.36 \pm 0.02$ & $15.58 \pm 0.3$ & $15.12 \pm 0.2$ \\
$25 / 01 / 2012,06: 35$ & -63.3 & -53.3 & 0.46 & 34.28 & 100 & $15.52 \pm 0.02$ & $15.58 \pm 0.3$ & $14.96 \pm 0.2$ \\
\hline
\end{tabular}

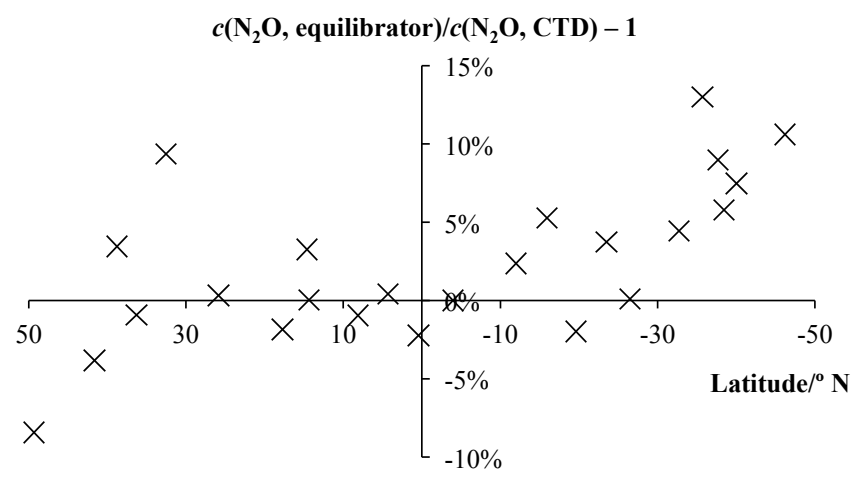

Figure 9. Difference between equilibrator and discrete $\mathrm{N}_{2} \mathrm{O}$ measurements from the CTD rosette (Rhee et al., 2009).

measurements, this could point towards a potential offset, either due to the analytical method or source of the water. In subsequent tests, the flow at the equilibrator vent was measured as $\pm 0.3 \mathrm{~mL} \mathrm{~min}^{-1}$. As the gas flow through the equilibrator is much higher $\left(100\right.$ and $400 \mathrm{~mL} \mathrm{~min}^{-1}$ respectively during AMT20 and JR255A), this cannot explain the lower $\mathrm{N}_{2} \mathrm{O}$ concentrations measured by the equilibrator. Also, the $\mathrm{N}_{2} \mathrm{O}$ mole fraction in laboratory air is close to or slightly above that of dissolved air, so the minor vent flow cannot explain the small, statistically insignificant differences between equilibrator and discrete measurements. Another potential explanation could be the consumption of $\mathrm{N}_{2} \mathrm{O}$ in anoxic biofilms within the ship's seawater pipes (Juranek et al., 2010). Foster et al. (2009) also cite a personal communication by Hermann Bange, who found loss of methane in underway sampling systems, but apparently no problems for $\mathrm{N}_{2} \mathrm{O}$.

There is actually further evidence for offsets between discrete and underway $\mathrm{N}_{2} \mathrm{O}$ measurements during a previous AMT cruise (AMT7, 1998) in the paper by Rhee et al. (2009). On average, the difference of equilibrator to discrete CTD measurements is $(2.2 \pm 5.7) \%$, but the range of deviations is from -8 to $+13 \%$, with lower values nearer the beginning of the cruise at $50^{\circ} \mathrm{N}$ (Fig. 9).

In future, GC-MS or GC-ECD samples from the pumped seawater supply should be compared with rosette samples to check that there are no biases due to the condition of the ship's seawater intake.

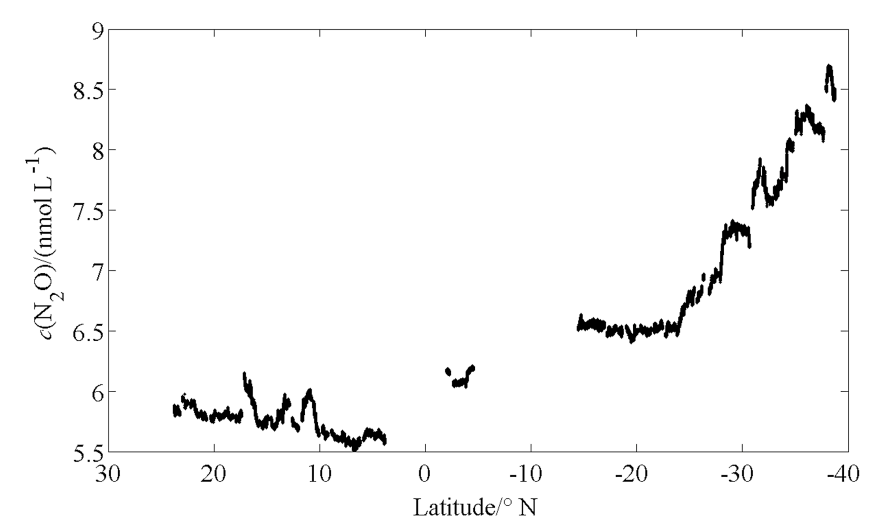

Figure 10. $\mathrm{N}_{2} \mathrm{O}$ concentrations in surface waters during the cruise.

\subsection{Surface ocean measurements}

The coupled system of the $\mathrm{N}_{2} \mathrm{O}$ analyser and equilibrator was tested in the field during AMT20 in boreal autumn 2010. The system worked well initially, but two problems occurred: (1) stagnant water flow through the equilibrator on several occasions, and (2) the measured values for the $\mathrm{N}_{2} \mathrm{O}$ reference gas drifted (Fig. 6).

Measurements of dissolved $\mathrm{N}_{2} \mathrm{O}$ in the surface ocean were collected between $24^{\circ} \mathrm{N}$ and $39^{\circ} \mathrm{S}$. Due to the problems with the laser no data was collected between $4^{\circ} \mathrm{N}$ and $2^{\circ} \mathrm{S}$ and between 5 and $14^{\circ} \mathrm{S}$ (Fig. 4). $\mathrm{N}_{2} \mathrm{O}$ concentrations in surface waters ranged from 5.5 to $8.6 \mathrm{nmol} \mathrm{L}^{-1}$, with lowest average concentrations measured in the North Atlantic Gyre between 24 and $11^{\circ} \mathrm{N}$ (Fig. 10, Table 2). Surface waters were slightly undersaturated. However, towards the southern limb of the gyre, an increase in $\mathrm{N}_{2} \mathrm{O}$ saturations above mean values of $99.0 \%$ were observed on three occasions between 20 and $11^{\circ} \mathrm{N}$. These periods lasted 14,4 and $12 \mathrm{~h}$, respectively, while saturations increased up to $104 \%$ (Fig. 11b, arrows).

Potential sources for $\mathrm{N}_{2} \mathrm{O}$ could be entrainment of deep waters into the mixed layer or advection from the oxygen minimum zone of the Mauritanian upwelling. However, no correlation between $\mathrm{N}_{2} \mathrm{O}$ saturation and sea surface temperature or $\mathrm{O}_{2}$ saturation was observed. Therefore, deep-water entrainment is unlikely to be the cause of the relatively high $\mathrm{N}_{2} \mathrm{O}$ saturations. Another potential source could be in situ 


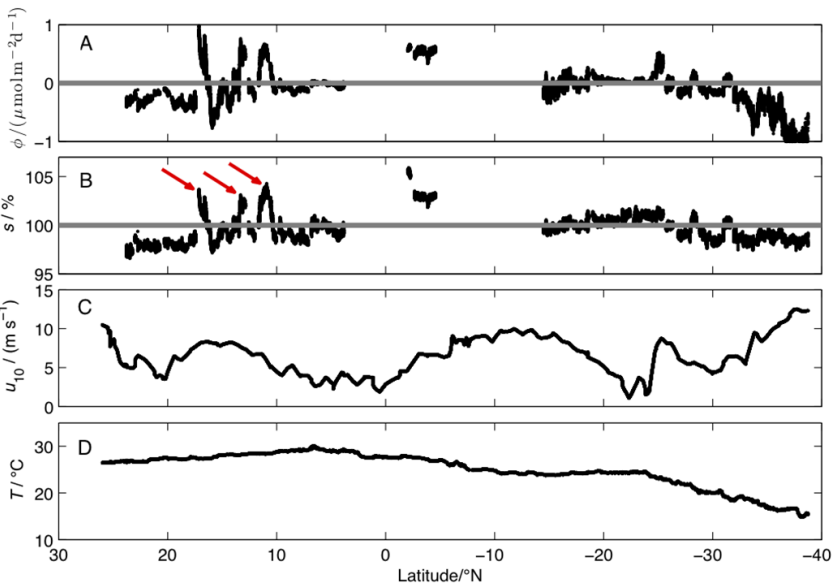

Figure 11. (A): Sea-to-air $\mathrm{N}_{2} \mathrm{O}$ flux, grey line denotes zero flux. Positive values indicate fluxes from sea to air. (B): Surface water saturations, equilibrium saturation $100 \%$ indicated by grey line, arrows mark saturation-peaks between 20 and $10^{\circ} \mathrm{N}$ (see text for details). (C): Wind speed at $10 \mathrm{~m}$ height from ECMWF climatology for AMT20. (D): Sea surface temperature at inlet.

Table 2. Mean $\mathrm{N}_{2} \mathrm{O}$ concentration, saturation and air-sea flux for the northern gyre $\left(24-11^{\circ} \mathrm{N}\right)$, equatorial region $\left(11^{\circ} \mathrm{N}-5^{\circ} \mathrm{S}\right.$, with gaps between $4^{\circ} \mathrm{N}$ and $\left.2^{\circ} \mathrm{S}\right)$ and southern gyre $\left(14-39^{\circ} \mathrm{S}\right)$.

\begin{tabular}{llll}
\hline Latitude & $\begin{array}{l}c\left(\mathrm{~N}_{2} \mathrm{O}\right) / \\
\left(\mathrm{nmol} \mathrm{L}^{-1}\right)\end{array}$ & $\begin{array}{l}s\left(\mathrm{~N}_{2} \mathrm{O}\right) / \\
\%\end{array}$ & $\begin{array}{l}\Phi / \\
(\mu \mathrm{mol} \mathrm{m}\end{array}$ \\
\hline $24-11^{\circ} \mathrm{N}$ & $5.8 \pm 0.1$ & $99.0 \pm 1.6$ & $-0.14 \pm 0.31$ \\
$11^{\circ} \mathrm{N}-5^{\circ} \mathrm{S}$ & $5.8 \pm 0.2$ & $100.4 \pm 1.8$ & $0.11 \pm 0.26$ \\
$14-39^{\circ} \mathrm{S}$ & $7.1 \pm 0.7$ & $99.7 \pm 1.0$ & $-0.16 \pm 0.33$ \\
\hline
\end{tabular}

production by nitrification or nitrifier denitrification. High rates of nitrogen fixation were previously observed in this region (Moore et al., 2009) and could provide a substrate for $\mathrm{N}_{2} \mathrm{O}$-producing bacteria. Forster et al. (2009) found average saturations of $104 \%$ during spring but $97 \%$ saturation during autumn in the latitude band between 26 and $11^{\circ} \mathrm{N}$, comparable to the $99 \%$ mean saturation measured in autumn for this study. More data are needed to confirm whether there is a real seasonal trend towards lower $\mathrm{N}_{2} \mathrm{O}$ saturations in the North Atlantic Gyre during boreal autumn.

The highest saturations of up to $107 \%$ were found close to the Equator. However, average saturations for the equatorial region between $11^{\circ} \mathrm{N}$ and $5^{\circ} \mathrm{S}$ were only $100.4 \%$. Surface saturations of on average 104-109\% were previously reported for this region (Walter et al., 2004; Forster et al., 2009; Oudot et al., 2002). Rhee et al. (2009) found maximum saturations of $110 \%$ at the Equator. Unfortunately, no data could be collected directly at the Equator, due to analyser maintenance between $5^{\circ} \mathrm{N}$ and $2^{\circ} \mathrm{S}$. High surface saturations can be expected due to equatorial upwelling of $\mathrm{N}_{2} \mathrm{O}$-rich waters. $\mathrm{N}_{2} \mathrm{O}$ saturations of $99.3 \%$ and the lowest $\mathrm{N}_{2} \mathrm{O}$ concentrations were measured between $10.6-5.8^{\circ} \mathrm{N}$ and $27.5-31.5^{\circ} \mathrm{W}$,

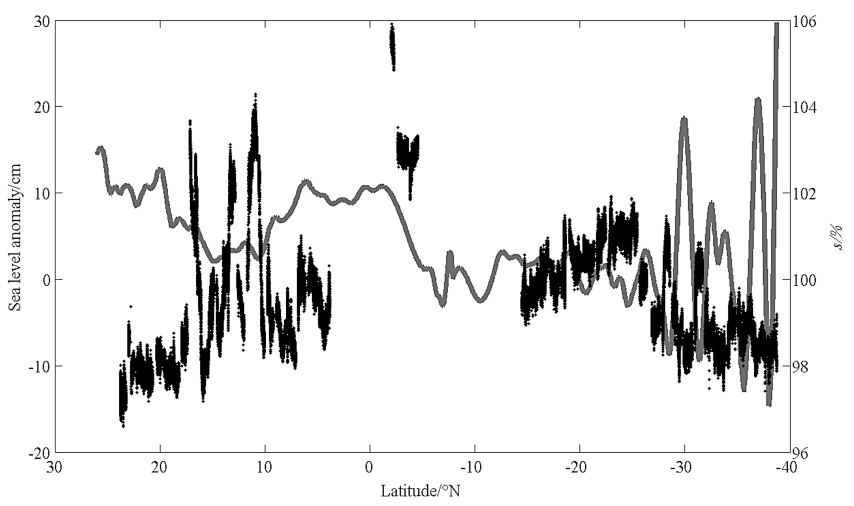

Figure 12. Meridional variations in sea level height anomaly (grey line, left axis) and $\mathrm{N}_{2} \mathrm{O}$ saturation (black dots, right axis).

associated with low salinities. Walter et al. (2004) observed similarly low saturations of about $100 \%$ in this region and related it to a retroflection of the North Brazil Current, advecting low-salinity Amazon plume waters into the North Equatorial Countercurrent (NECC).

$\mathrm{N}_{2} \mathrm{O}$ concentrations increased south of $14^{\circ} \mathrm{S}$ and reached mean values of $7.7 \mathrm{nmol} \mathrm{L}^{-1}$ between 25 and $39^{\circ} \mathrm{S}$. While surface waters in the latitudinal band of $14-25^{\circ} \mathrm{S}$ were on average in equilibrium with the atmosphere, saturations decreased south of $25^{\circ} \mathrm{S}$ (Fig. 11b) as water temperature decreased. Mean saturations between 14 and $39^{\circ} \mathrm{S}$ were $99.7 \%$, similar to $101 \%$ saturation observed in austral spring (Forster et al., 2009; Rhee et al., 2009), while average saturations in austral autumn were higher (104\%, Forster et al., 2009). This was attributed to accumulated $\mathrm{N}_{2} \mathrm{O}$ production during spring and summer.

Eddies can bring thermocline waters with higher nutrient and $\mathrm{N}_{2} \mathrm{O}$ concentrations into the mixed layer (McGillicuddy et al., 2007). This might stimulate in situ $\mathrm{N}_{2} \mathrm{O}$ production from remineralisation of additional biomass as well as increase the mixed layer inventory simply due to mixing with deeper waters with higher $\mathrm{N}_{2} \mathrm{O}$ concentrations. Satellite altimeter products from Ssalto/Duacs (gridded sea level anomalies, $1 / 3^{\circ} \times$ $1 / 3^{\circ}$ grid; http://www.aviso.oceanobs.com/en/data/products/ sea-surface-height-products/global.html) were used to trace eddies. No clear relationship between sea level anomalies (SLA) and saturations was observed in the northern gyre (Fig. 12). Between 28 and $36^{\circ} \mathrm{S}$, however, higher $\mathrm{N}_{2} \mathrm{O}$ saturations seem to be associated with negative SLAs, while lower saturations occur with positive SLAs. This could point towards upwelling eddies, introducing waters with higher $\mathrm{N}_{2} \mathrm{O}$ concentrations, possibly originating from the Benguela upwelling, to the South Atlantic Gyre region.

Generally, oligotrophic gyres are expected to be weak $\mathrm{N}_{2} \mathrm{O}$ sinks, especially in winter, due to thermal effects, with a potential for weak sources in summer while coastal and equatorial upwelling zones are sources of $\mathrm{N}_{2} \mathrm{O}$ (Nevison et al., 
1995; Suntharalingam and Sarmiento, 2000). The gyres in both hemispheres were acting as sinks for atmospheric $\mathrm{N}_{2} \mathrm{O}$ at the time of the survey, due to slightly undersaturated surface waters (Fig. 11a). Average fluxes for the region between 24 and $11^{\circ} \mathrm{N}$ were $(-0.14 \pm 0.31) \mu \mathrm{mol} \mathrm{m}^{-2} \mathrm{~d}^{-1}$ and $(-0.16 \pm 0.33) \mu \mathrm{mol} \mathrm{m}^{-2} \mathrm{~d}^{-1}$ for $14-39^{\circ} \mathrm{S}$ (Table 2). For comparison, Forster et al. (2009) observed negative sea-toair $\mathrm{N}_{2} \mathrm{O}$ fluxes between -0.02 and $-0.04 \mu \mathrm{mol} \mathrm{m}^{-2} \mathrm{~d}^{-1}$ between 26 and $11^{\circ} \mathrm{N}$ during autumn, corresponding to weak $\mathrm{N}_{2} \mathrm{O}$ uptake. Fluxes in spring were positive. The southern gyre was found to be a source of $\mathrm{N}_{2} \mathrm{O}$ at all times. They pointed out, that emissions in spring were four times higher between $6-40^{\circ} \mathrm{S}$ than in autumn, rather due to varying $\mathrm{N}_{2} \mathrm{O}$ inventories in the mixed layer than to changing wind speeds. This points towards remarkable interannual differences in the oceanic $\mathrm{N}_{2} \mathrm{O}$ source and, as shown in this study, also intraannual variation.

The equatorial region was a source of $\mathrm{N}_{2} \mathrm{O}$ to the atmosphere where high surface saturations coincided with relatively high wind speeds. The average flux was $0.53 \mu \mathrm{mol} \mathrm{m}{ }^{-2} \mathrm{~d}^{-1}$ between $10^{\circ}$ and $3^{\circ} \mathrm{N}$, which is most likely an underestimation, due to analyser downtime. Comparable values of $0.52 \mu \mathrm{mol} \mathrm{m}{ }^{-2} \mathrm{~d}^{-1}$ were previously observed for the latitudinal band between 12 and $1.5^{\circ} \mathrm{N}$ (Walter et al., 2004). For latitudes between $11^{\circ} \mathrm{N}$ and $5^{\circ} \mathrm{S}$, the Western Tropical Atlantic Longhurst province, emissions of $(0.11 \pm 0.26) \mu \mathrm{mol} \mathrm{m}{ }^{-2} \mathrm{~d}^{-1}$ were measured. For comparison, $0.16-0.33 \mu \mathrm{mol} \mathrm{m} \mathrm{m}^{-2} \mathrm{~d}^{-1}$ were previously reported from the Atlantic Ocean during austral spring (Forster et al., 2009). There might be seasonal variability, as higher emissions were observed during austral autumn $\left(1.17-2.13 \mu \mathrm{mol} \mathrm{m}^{-2} \mathrm{~d}^{-1}\right.$; Forster et al., 2009).

Generally, saturations reported here are within the lower range of previously published values for the tropical and subtropical Atlantic which might be due to $\mathrm{N}_{2} \mathrm{O}$ consumption in anoxic biofilms within the pumped seawater system as discussed above.

\section{Conclusions and outlook}

Laboratory and field tests showed that the Los Gatos $\mathrm{N}_{2} \mathrm{O} / \mathrm{CO}$ analyser can be coupled with an equilibrator to reliably measure both, atmospheric and marine $\mathrm{N}_{2} \mathrm{O}$ concentrations. Small-scale changes of concentrations could be observed, giving a very detailed picture of the marine $\mathrm{N}_{2} \mathrm{O}$ budget. This is important for monitoring environments that are highly variable in space and time, such as fronts, upwelling and coastal regions.

The system is virtually ready for deployment on platforms of opportunity as shown for a similar setup for methane and carbon dioxide measurements (Gülzow et al., 2011). It records high-resolution data $\left(\mathrm{N}_{2} \mathrm{O}\right.$ mole fractions recorded at a frequency of $1 \mathrm{~s}^{-1}, \tau=203 \mathrm{~s}$ ) while operation is low maintenance and can be easily automated. This is an advantage to labour-intensive discrete sampling techniques. Calibration can be automated and atmospheric and marine dissolved gas measurements can be analysed in alternation using the same instrument. The resolution of the described system is good (relaxation time of $140 \mathrm{~s}$ for a headspace flow rate of $400 \mathrm{~mL} \mathrm{~min}^{-1}$ ), but response times could be reduced further by increasing the headspace flow, decreasing the headspace volume or, potentially, by decreasing the instrument operating pressure and measurement cell volume. The instrument is protected from water by a cold trap and a solenoid valve connected to a humidity detector. The cold trap currently requires manually draining every $2-3$ days, but this could be automated as for $\mathrm{CO}_{2}$ analysers. Another remaining operator-dependent task is cleaning of the seawater flow regulator, which could be avoided by using screens and prefilters. However, this is a problem common to all equilibrator techniques. Measurements of depth profiles would require large sample sizes or a pumped CTD due to the relatively long relaxation time of the equilibrator. For depth profiles, headspace sampling and GC analysis of discrete samples would therefore be the preferred option.

In addition, an effective underway system should comprise the following characteristics:

- A calibration for temperature probes measuring seawater temperature in the equilibrator to a precision better than $0.01^{\circ} \mathrm{C}$.

- Use of a flow restrictor or flow regulator to control water flow through the equilibrator.

- Use of three reference gases for improved calibration and drift correction in case the difference between seawater concentrations and atmospheric values are is higher than experienced during AMT20.

The laser drift experienced during AMT20 does not relate to the experimental setup and the instrument has been deployed successfully after laser replacement without further issues. Saturation values from measurements with the analyser-equilibrator setup are comparable to previous studies using gas chromatography and the agreement with atmospheric AGAGE measurements is excellent. First comparisons with GC-MS measurements show agreement between the two methods within measurement uncertainties. Precision for the ICOS analyser under field conditions after correction for analyser offset and drift are

- $0.2 \mathrm{nmol} \mathrm{mol}^{-1}$ over $40 \mathrm{~min}$ for reference gas injections

- 0.5 to $0.7 \mathrm{nmol} \mathrm{mol}^{-1}$ for atmospheric measurements

$-0.2 \mathrm{nmol} \mathrm{mol}^{-1}$ over $5 \mathrm{~min}$ for equilibrator measurements. 
Further data comparison with GC-ECD measurements in the laboratory and during field campaigns should be implemented in the future, as well as testing for differences between rosette and underway samples. Another interesting test would be comparing the performance of this coupled equilibrator-analyser setup with other equilibrator types and laser-based $\mathrm{N}_{2} \mathrm{O}$ analysers of different manufacturers, e.g. as part of the European FP7 InGOS project (http://www.ingos-infrastructure.eu), the SCOR Working Group on dissolved $\mathrm{N}_{2} \mathrm{O}$ and $\mathrm{CH}_{4}$ measurements and the SOLAS and COST-sponsored $\mathrm{CH}_{4}-\mathrm{N}_{2} \mathrm{O}$ database MEMENTO (http://memento.geomar.de).

Acknowledgements. We would like to thank captain and crew of RRS James Cook and principal scientist Andy Rees for their support during AMT20, as well as BODC for underway sea surface data. Helpful discussions with Grant Forster and Sunke Schmidtko (UEA) are gratefully acknowledged. We would also like to thank Doug Baer and Robert Provencal (Los Gatos Research) for support with the $\mathrm{N}_{2} \mathrm{O} / \mathrm{CO}$ analyser and Dorothee Bakker for providing the equilibrator used in this study. Special thanks go to Gareth A. Lee for invaluable help with the laboratory experiments and fieldwork preparation. This study was supported by the European Community's Seventh Framework Programme (FP7/2007-2013) under grant agreement number 237890 (Marie Curie Initial Training Network "INTRAMIF") and UK Natural Environment Research Council National Capability funding to Plymouth Marine Laboratory and the National Oceanography Centre, Southampton. This is contribution number 222 of the AMT programme.

Edited by: M. Hoppema

\section{References}

Arévalo-Martínez, D. L., Beyer, M., Krumbholz, M., Piller, I., Kock, A., Steinhoff, T., Körtzinger, A., and Bange, H. W.: A new method for continuous measurements of oceanic and atmospheric $\mathrm{N}_{2} \mathrm{O}$, $\mathrm{CO}$ and $\mathrm{CO}_{2}$ : performance of off-axis integrated cavity output spectroscopy (OA-ICOS) coupled to nondispersive infrared detection (NDIR), Ocean Sci., 9, 1071-1087, doi:10.5194/os-9-1071-2013, 2013.

Baer, D. S., Paul, J. B., Gupta, M., and O'Keefe, A.: Sensitive absorption measurements in the near-infrared region using off-axis integrated-cavity-output spectroscopy, Appl. Phys. B, 75, 261265, 2002.

Becker, M., Andersen, N., Fiedler, B., Fietzek, P., Körtzinger, A., Steinhoff, T., and Friedrichs, G.: Using cavity ringdown spectroscopy for continuous monitoring of $\delta^{13} \mathrm{C}\left(\mathrm{CO}_{2}\right)$ and $f \mathrm{CO}_{2}$ in the surface ocean, Limnol. Oceanogr., 10, 752-766, 2012.

Butler, J. H., Elkins, J. W., Thompson, T. M., and Egan, K. B.: Tropospheric and dissolved $\mathrm{N}_{2} \mathrm{O}$ of the west Pacific and east Indian Oceans during the El Nino Southern Oscillation event of 1987, J. Geophys. Res., 94, 14865-14814, 1989.

Codispoti, L. A.: Interesting times for marine $\mathrm{N}_{2} \mathrm{O}$, Science, 327 , 1339, 2010.
Cohen, Y. and Gordon, L. I.: Nitrous oxide in the oxygen minimum of the eastern tropical North Pacific: Evidence for its consumption during denitrification and possible mechanisms for its production, Deep Sea Res., 25, 509-524, 1978.

Cooper, D. J., Watson, A. J., and Ling, R. D.: Variation of $\mathrm{pCO}_{2}$ along a North Atlantic shipping route (UK to the Caribbean): A year of automated observations, Marine Chem., 60, 147-164, 1998.

Crutzen, P. J.: The influence of nitrogen oxides on the atmospheric ozone content, Q. J. R. Meteorol. Soc., 96, 320-325, 1970.

Denman, K. L., Brasseur, G., Chidthaisong, A., Ciais, P., Cox, P. M., Dickinson, R. E., Hauglustaine, D., Heinze, C., Holland, E., Jacob, D., Lohmann, U., Ramachandran, S., da Silva Dias, P. L., Wofsy, S. C., and Zhang, X.: Couplings Between Changes in the Climate System and Biogeochemistry, in: Climate Change 2007: The Physical Science Basis, Contribution of Working Group I to the Fourth Assessment Report of the Intergovernmental Panel on Climate Change, edited by: Solomon, S., Qin, D., Manning, M., Chen, Z., Marquis, M., Averyt, K. B., Tignor, M., and Miller, H. L., Cambridge University Press, Cambridge, United Kingdom and New York, NY, USA, 2007.

Elkins, J. W., Wofsy, S. C., McElroy, M. B., Kolb, C. E., and Kaplan, W. A.: Aquatic sources and sinks for nitrous oxide, Nature, 275, 602-606, 1978.

Forster, G., Upstill-Goddard, R. C., Gist, N., Robinson, C., Uher, G., and Woodward, E. M. S.: Nitrous oxide and methane in the Atlantic Ocean between 50 degrees $\mathrm{N}$ and 52 degrees S: Latitudinal distribution and sea-to-air flux, Deep-Sea Res. Pt. II, 56, 964-976, doi:10.1016/j.dsr2.2008.12.002, 2009.

Forster, P., Ramaswamy, V., Artaxo, P., Berntsen, T., Betts, R., Fahey, D. W., Haywood, J., Lean, J., Lowe, D. C., Myhre, G., Nganga, J., Prinn, R., Raga, G., Schulz, M., and Van Dorland, R.: Changes in Atmospheric Constituents and Radiative Forcing, in: Climate Change 2007: The Physical Science Basis. Contribution of Working Group I to the Fourth Assessment Report of the Intergovernmental Panel on Climate Change, edited by: Solomon, S., Qin, D., Manning, M., Chen, Z., Marquis, M., Averyt, K. B., Tignor, M., and Miller, H. L., Cambridge University Press, Cambridge, United Kingdom and New York, NY, USA, 2007.

Goreau, T. J., Kaplan, W. A., Wofsy, S. C., McElroy, M. B., Valois, F. W., and Watson, S. W.: Production of $\mathrm{NO}_{2}^{-}$and $\mathrm{N}_{2} \mathrm{O}$ by nitrifying bacteria at reduced concentrations of oxygen, Appl. Environ. Microbiol., 40, 526-532, 1980.

Gülzow, W., Rehder, G., Schneider, B., Deimling, J. S., and Sadkowiak, B.: A new method for continuous measurement of methane and carbon dioxide in surface waters using off-axis integrated cavity output spectroscopy (ICOS): An example from the Baltic Sea, Limnol. Oceanogr. Methods, 9, 176-184, 2011.

Juranek, L. W., Hamme, R. C., Kaiser, J., Wanninkhof, R., and Quay, P. D.: Evidence of $\mathrm{O}_{2}$ consumption in underway seawater lines: Implications for air-sea $\mathrm{O}_{2}$ and $\mathrm{CO}_{2}$ fluxes, Geophys. Res. Lett., 37, L01601, doi:10.1029/2009GL040423, 2010.

Knowles, R.: Denitrification, Microbiol. Rev., 46, 43-70, 1982.

Liss, P. S. and Merlivat, L.: Air-sea gas exchange rates: Introduction and synthesis, The role of air-sea exchange in geochemical cycling, 185, 113-127, 1986.

Löscher, C. R., Kock, A., Könneke, M., LaRoche, J., Bange, H. W., and Schmitz, R. A.: Production of oceanic nitrous oxide 
by ammonia-oxidizing archaea, Biogeosciences, 9, 2419-2429, doi:10.5194/bg-9-2419-2012, 2012.

McGillicuddy, D. J., Anderson, L. A., Bates, N. R., Bibby, T., Buesseler, K. O., Carlson, C. A., Davis, C. S., Ewart, C., Falkowski, P. G., and Goldthwait, S. A.: Eddy/wind interactions stimulate extraordinary mid-ocean plankton blooms, Science, 316, 10211026, 2007.

McIlvin, M. R. and Casciotti, K. L.: Fully automated system for stable isotopic analyses of dissolved nitrous oxide at natural abundance levels, Limnol. Oceanogr. Methods, 8, 54-66, 2010.

Moore, C. M., Mills, M. M., Achterberg, E. P., Geider, R. J., LaRoche, J., Lucas, M. I., McDonagh, E. L., Pan, X., Poulton, A. J., and Rijkenberg, M. J. A.: Large-scale distribution of Atlantic nitrogen fixation controlled by iron availability, Nat. Geosci., 2, 867-871, 2009.

Nevison, C. D., Weiss, R. F., and Erickson, D. J.: Global oceanic emissions of nitrous oxide, J. Geophys. Res., 100, 15809-15820, 1995.

Nightingale, P. D., Malin, G., Law, C. S., Watson, A. J., Liss, P. S., Liddicoat, M. I., Boutin, J., and Upstill-Goddard, R. C.: In situ evaluation of air-sea gas exchange parameterizations using novel conservative and volatile tracers, Global Biogeochem. Cy., 14, 373-387, 2000.

Oudot, C., Jean-Baptiste, P., FourrÈ, E., Mormiche, C., Guevel, M., Ternon, J. F., and Le Corre, P.: Transatlantic equatorial distribution of nitrous oxide and methane, Deep Sea Res. Pt. I, 49, 1175-1193, 2002.

Popp, B. N., Westley, M. B., Toyoda, S., Miwa, T., Dore, J. E., Yoshida, N., Rust, T. M., Sansone, F. J., Russ, M. E., Ostrom, N. E., and Ostrom, P. H.: Nitrogen and oxygen isotopomeric constraints on the origins and sea-to-air flux of $\mathrm{N}_{2} \mathrm{O}$ in the oligotrophic subtropical North Pacific gyre, Global Biogeochem. Cy., 16, 12-1-12-10, doi:10.1029/2001gb001806, 2002.

Poth, M. and Focht, D. D.: ${ }^{15} \mathrm{~N}$ kinetic analysis of $\mathrm{N}_{2} \mathrm{O}$ production by Nitrosomonas europaea: an examination of nitrifier denitrification, Appl. Environ. Microbiol., 49, 1134-1141, 1985.

Prinn, R., Weiss, R., Fraser, P., Simmonds, P., Cunnold, D., Alyea, F., O'Doherty, S., Salameh, P., Miller, B., and Huang, J.: A history of chemically and radiatively important gases in air deduced from ALE/GAGE/AGAGE, J. Geophys. Res. Atmos. (19842012), 105, 17751-17792, 2000.

Rafelski, L. E., Paplawsky, B., and Keeling, R. F.: An equilibrator system to measure dissolved oxygen and its isotopes, J. Atmos. Ocean. Technol., 30, 361-377, doi:10.1175/JTECH-D-1200074.1, 2012.

Ravishankara, A. R., Daniel, J. S., and Portmann, R. W.: Nitrous oxide $\left(\mathrm{N}_{2} \mathrm{O}\right)$ : the dominant ozone-depleting substance emitted in the 21st century, Science, 326, 123-125, doi:10.1126/science.1176985, 2009.

Reuer, M. K., Barnett, B. A., Bender, M. L., Falkowski, P. G., and Hendricks, M. B.: New estimates of Southern Ocean biological production rates from $\mathrm{O}_{2} / \mathrm{Ar}$ ratios and the triple isotope composition of $\mathrm{O}_{2}$, Deep Sea Res. Pt. I, 54, 951-974, 2007.

Rhee, T. S., Kettle, A. J., and Andreae, M. O.: Methane and nitrous oxide emissions from the ocean: A reassessment using basin-wide observations in the Atlantic, J. Geophys. Res., 114, D12304, doi:10.1029/2008JD011662, 2009.
Röckmann, T., Kaiser, J., Brenninkmeijer, C. A. M., and Brand, W. A.: Gas chromatography/isotope-ratio mass spectrometry method for high-precision position-dependent ${ }^{15} \mathrm{~N}$ and ${ }^{18} \mathrm{O}$ measurements of atmospheric nitrous oxide, Rapid Communications Mass Spectrometry, 17, 1897-1908, doi:10.1002/rcm.1132, 2003.

Suntharalingam, P. and Sarmiento, J. L.: Factors governing the oceanic nitrous oxide distribution: Simulations with an ocean general circulation model, Global Biogeochem. Cy., 14, 429454, 2000.

Sutka, R. L., Ostrom, N. E., Ostrom, P. H., and Phanikumar, M. S.: Stable nitrogen isotope dynamics of dissolved nitrate in a transect from the North Pacific Subtropical Gyre to the Eastern Tropical North Pacific, Geochim. Cosmochim. Acta, 68, 517527, doi:10.1016/S0016-7037(03)00483-6, 2004.

Sutka, R. L., Ostrom, N. E., Ostrom, P. H., Breznak, J. A., Gandhi, H., Pitt, A. J., and Li, F.: Distinguishing nitrous oxide production from nitrification and denitrification on the basis of isotopomer abundances, Appl. Environ. Microbiol., 72, 638-644, doi:10.1128/aem.72.1.638-644.2006, 2006.

Sweeney, C., Gloor, E., Jacobsen, A. R., Key, R. M., McKinley, G., Sarmiento, J. L., and Wanninkhof, R.: Constraining global air-sea gas exchange for $\mathrm{CO}_{2}$ with recent bomb ${ }^{14} \mathrm{C}$ measurements, Global Biogeochem. Cy., 21, GB2015, doi:10.1029/2006GB002784, 2007.

Walter, S., Bange, H. W., and Wallace, D. W. R.: Nitrous oxide in the surface layer of the tropical North Atlantic Ocean along a west to east transect, Geophys. Res. Lett., 31, L23S07, doi:10.1029/2004GL019937, 2004.

Walter, S., Bange, H. W., Breitenbach, U., and Wallace, D. W. R.: Nitrous oxide in the North Atlantic Ocean, Biogeosciences, 3, 607-619, doi:10.5194/bg-3-607-2006, 2006.

Wanninkhof, R.: Relationship between wind speed and gas exchange, J. Geophys. Res, 97, 7373-7382, 1992.

Weiss, R. F.: Determinations of carbon dioxide and methane by dual catalyst flame ionization chromatography and nitrous oxide by electron capture chromatography, J. Chromatogr. Sci., 19, 611$616,1981$.

Weiss, R. F. and Price, B. A.: Nitrous oxide solubility in water and seawater, Marine Chem., 8, 347-359, 1980.

Weiss, R. F., Van Woy, F. A., and Salameh, P. K.: Surface water and atmospheric carbon dioxide and nitrous oxide observations by shipboard automated gas chromatography: Results from expeditions between 1977 and 1990, Oak Ridge National Lab., TN (United States), Carbon Dioxide Information Analysis Center, 1992.

Wuchter, C., Abbas, B., Coolen, M. J. L., Herfort, L., Van Bleijswijk, J., Timmers, P., Strous, M., Teira, E., Herndl, G. J., and Middelburg, J. J.: Archaeal nitrification in the ocean, Proc. Natl. Aca. Sci., 103, 12317-12322, doi:10.1073/pnas.0600756103, 2006.

Yoshida, N., Morimoto, H., Hirano, M., Koike, I., Matsuo, S., Wada, E., Saino, T., and Hattori, A.: Nitrification rates and ${ }^{15} \mathrm{~N}$ abundances of $\mathrm{N}_{2} \mathrm{O}$ and $\mathrm{NO}_{3}^{-}$in the western North Pacific, Nature, 341, 895-897, 1989.

Yoshinari, T.: Nitrous oxide in the sea, Marine Chem., 4, 189-202, 1976. 